\title{
BIO-ASSAY OF NITROGEN AVAILABLE TO TWO SPECIES OF PHYTOPLANKTON IN AN OFF-SHORE WATER
}

\author{
By H. W. HARVEY, F.R.S. \\ The Plymouth Laboratory
}

In a series of preliminary trials, off-shore water, collected during the summer of 1955 and containing only small concentrations of nitrogen and phosphorus available to plants, was filtered, pasteurized, enriched with phosphate, manganese and iron, inseminated with washed Phaeodactylum tricornutum and portioned into a series of flasks. To these were added varying quantities of nitrate, raising the concentration, in steps, up to $40 \mu \mathrm{g}$ nitrate-N per litre. The flasks were illuminated, either in a north window or in front of a 'warm daylight' fluorescent strip, precautions being taken to prevent contamination with ammonia or oxides of nitrogen in the atmosphere. Growth of the algae was followed by withdrawing samples at intervals, after shaking, and measuring their optical density in a $10 \mathrm{~cm}$ cuvette.

After an initial lag period and the following period of exponential growth, during which the nitrogen source was used and consequently synthesis of chlorophyll ceased, the rate of increase in optical density slowed, and persisted at a regular slow rate for several days.

During this post-exponential period of growth the increase in optical density due to added nitrate was almost directly proportional to the quantity of nitrogen source which had been added.

The observations of optical density (light path $10 \mathrm{~cm}$ ), shown in Table I, were made in an experiment after 7,9 and II days illumination. The initial o.D. (IO cm) of the inseminated water was 0.007 , and the inseminum was nitrogen-deficient and had a long lag period before growth started.

TABLE 1. INCREASE IN OPTICAL DENSITY DURING POST-EXPONENTIAL PERIOD

\begin{tabular}{|c|c|c|c|c|}
\hline Flask no. & o.D. (IO $\mathrm{cm}$ ) after & 7 days & 9 days & II days \\
\hline $\left.\begin{array}{l}1 \\
2\end{array}\right\}$ & $\begin{array}{l}\text { With no added } \\
\text { nitrate }\end{array}$ & $\left\{\begin{array}{l}0.035 \\
0.041\end{array}\right.$ & $\begin{array}{l}0.033 \\
0.046\end{array}$ & $\begin{array}{l}0.050 \\
0.050\end{array}$ \\
\hline $\left.\begin{array}{l}3 \\
4\end{array}\right)$ & $+20 \mu \mathrm{g} / 1 . \mathrm{NO}_{3} \mathrm{~N}$ & $\left\{\begin{array}{l}0.063 \\
0.066\end{array}\right.$ & $\begin{array}{l}0.070 \\
0.071\end{array}$ & $\begin{array}{l}0.078 \\
0.080\end{array}$ \\
\hline 5) & $+40 \mu \mathrm{g} / 1 . \mathrm{NO}_{3} \mathrm{~N}$ & $\left\{\begin{array}{l}0.084 \\
0.085\end{array}\right.$ & $\begin{array}{l}\text { O.IOI } \\
\text { O.IO2 }\end{array}$ & $\begin{array}{l}\text { O.106 } \\
\text { O.II4 }\end{array}$ \\
\hline 7 & - & 0.090 & 0.095 & 0.112 \\
\hline \multicolumn{5}{|c|}{ to addition: } \\
\hline $\begin{array}{l}\text { of } 2 \\
\text { of } 4\end{array}$ & & $\begin{array}{l}0.026 \\
0.049\end{array}$ & $\begin{array}{l}0.030 \\
0.059\end{array}$ & $\begin{array}{l}0.029 \\
0.060\end{array}$ \\
\hline
\end{tabular}


In order to assay the available nitrogen present in a sample of water the following reasoning was employed. Provided the washed plant cells added as inseminum were wholly deficient in nitrogen, and consequently incapable of further growth unless supplied with a nitrogen source, then, at any particular time $T$ during post-exponential growth, the increase in optical density since the start of the experiment depends upon the concentration $C$ of available nitrogen in the water, and equals $C y \mu \mathrm{g} / \mathrm{N} / 1$. if $y$ is the increase in optical density due to the addition of I $\mu \mathrm{g}$ nitrate-N/1.

If, however, the plant cells added as inseminum were growing actively and capable of further carbon synthesis without a source of nitrogen, then the increase in optical density equals $C y+x$. The value of $x$ is directly proportional to the quantity of inseminum added. Therefore, $x$ is equal to the difference in the increases in optical density which have taken place in samples to which one unit and two unit quantities of inseminum have been added.

Hence from observations of these two increases and of the increase due to a known addition of available nitrogen, the value of $C$ can be calculated. Experiments indicated that throughout several days in which post-exponential growth was taking place, the value of $C$ remained the same within the limits of experimental error.

A bio-assay was made in water collected 20 miles off shore from Plymouth on I3 July 1955, from a depth of $15 \mathrm{~m}$.

The water was filtered, pasteurized, and enriched with $500 \mu \mathrm{g} / 1$. of phosphate-P, Iо $\mu \mathrm{g} / 1$. of manganese and Iо $\mu \mathrm{g} / 1$. of iron as ferrous dipyridyl.

Samples of this enriched water were analysed by Dr J. P. Riley, and was found to contain ro $\mu \mathrm{g}$ total inorganic nitrogen per litre by the method described by Riley and Sinhaseni (I957).

Part of the water was inseminated with Phaeodactylum tricornutum, the initial optical densities measured, and the flasks were kept in a north window. The optical densities were again measured on the fourth and sixth days, and from the observed increases on the sixth day the concentration $C$ was calculated (Table 2).

On the fourth day the nitrate added to flasks 5-8 had not exerted its full effect upon carbon synthesis.

The remainder of the water was inseminated with Chlorella stigmatophora and treated in the same way, providing the observations shown in Table 3.

On the sixth day some of the cells had started to disintegrate; the postexponential growth was of short duration compared with that of Phaeodactylum.

Since the average concentration of available nitrogen found by assay is similar to the concentration of total inorganic nitrogen found by analysis, it appears that only an insignificant quantity of organic nitrogen was used by 
these plants in the presence of their associated bacteria, although sea water contains a material quantity of organic nitrogen.

It is remarkable that so much organic nitrogen should remain in solution unattacked by bacteria in the sea-Krogh (I934) found some $240 \mu \mathrm{g}$ organic$\mathrm{N} / 1$. down to depths of $4750 \mathrm{~m}$-whereas organic phosphorus is not found at depths below $1000 \mathrm{~m}$.

TABLE 2. BIO-ASSAY OF CHANNEL WATER WITH PHAEODACTYLUM

\begin{tabular}{|c|c|c|c|c|}
\hline \multirow[b]{2}{*}{$\left.\begin{array}{c}\text { Flask no. } \\
\text { I } \\
2 \\
3 \\
4\end{array}\right\}$} & \multirow[b]{2}{*}{ Unit inseminum } & \multicolumn{3}{|c|}{ Optical density, $10 \mathrm{~cm}$ light path } \\
\hline & & $\begin{array}{l}\text { Initial } \\
\left\{\begin{array}{l}0.013 \\
0.012 \\
0.013 \\
0.013\end{array}\right.\end{array}$ & $\begin{array}{c}\text { On } 4 \text { th day } \\
0.035 \\
0.036 \\
0.036 \\
-\end{array}$ & $\begin{array}{c}\text { On 6th day } \\
0.036 \\
0.035 \\
0.036 \\
0.034\end{array}$ \\
\hline $\left.\begin{array}{l}5 \\
6 \\
7 \\
8\end{array}\right\}$ & $\begin{array}{l}\text { Unit inseminum } \\
+40 \mu \mathrm{g} \mathrm{NO}_{3} \mathrm{~N} / 1\end{array}$ & $\left\{\begin{array}{l}0.013 \\
0.014 \\
0.014 \\
0.017\end{array}\right.$ & $\begin{array}{c}0.072 \\
0.079 \\
0.078 \\
-\end{array}$ & $\begin{array}{l}0.081 \\
0.085 \\
0.088 \\
0.088\end{array}$ \\
\hline $\left.\begin{array}{r}9 \\
\text { Io } \\
\text { II } \\
\text { I2 }\end{array}\right\}$ & Double inseminum & $\left\{\begin{array}{l}0.022 \\
0.023 \\
0.027 \\
0.026\end{array}\right.$ & $\begin{array}{l}0.052 \\
0.052 \\
0.055 \\
-\end{array}$ & $\begin{array}{l}0.053 \\
0.054 \\
0.057 \\
0.057\end{array}$ \\
\hline
\end{tabular}

Calculated concentration of available nitrogen, $C=\mathrm{II} \cdot 5 \mu \mathrm{g} \mathrm{N} / 1$.

TABLE 3. BIO-ASSAY OF CHANNEL WATER WITH CHLORELLA

\begin{tabular}{|c|c|c|c|}
\hline \multirow[b]{2}{*}{$\left.\begin{array}{c}\text { Flask no. } \\
\text { I } \\
2 \\
3 \\
4\end{array}\right\}$} & \multirow[b]{2}{*}{ Single inseminum } & \multicolumn{2}{|c|}{ Optical density, $10 \mathrm{~cm}$ light pat } \\
\hline & & $\begin{array}{l}\text { Initial } \\
\left\{\begin{array}{l}0.01 \mathrm{I} \\
-\end{array}\right.\end{array}$ & $\begin{array}{c}\text { On } 4 \text { th day } \\
0.066 \\
0.061 \\
0.066 \\
0.063\end{array}$ \\
\hline $\left.\begin{array}{l}5 \\
6 \\
7 \\
8\end{array}\right\}$ & Single inseminum $+40 \mu \mathrm{g} \mathrm{NO}_{3} \mathrm{~N} / 1$. & $\left\{\begin{array}{l}\text { 二 } \\
\text { - }\end{array}\right.$ & $\begin{array}{l}0.127 \\
0.129 \\
0.132 \\
0.142\end{array}$ \\
\hline $\left.\begin{array}{r}9 \\
10 \\
\text { II } \\
\text { I2 }\end{array}\right\}$ & Double inseminum & $\left\{\begin{array}{l}0.025 \\
\text { 二 } \\
-\end{array}\right.$ & $\begin{array}{l}0.107 \\
0.127 \\
0.100 \\
0.107\end{array}$ \\
\hline
\end{tabular}

\section{SUMMARY}

A bio-assay of the nitrogen which was available to two phytoplankton species with their associated bacteria in an off-shore water is described.

The concentrations found by assay ( $\mathrm{I} \cdot 5$ and $\mathrm{I} 3 \mu \mathrm{g} \mathrm{N} / 1$.) were similar to the concentration of total inorganic nitrogen compounds found by analysis ( (o $\mu \mathrm{g} \mathrm{N} / 1$.). 
Of the organic nitrogen normally present in solution in sea water, an insignificant quantity appears to be available to the plant-bacteria community.

\section{REFERENCES}

KROGH, A., 1934. Conditions of life at great depths in the ocean. Ecol. Monogr., Vol. 4, pp. 430-39.

RILEY, J. P. and Sinhaseni, P., 1957. The determination of ammonia and total ionic inorganic nitrogen in sea water. F. mar. biol. Ass. U.K., Vol. 36, pp. I6I-68. 